\title{
Confidence to go the way science takes you
}

\author{
Anne Simonsen is a Professor at the Department of Molecular Medicine at the Institute of Basic Medical Sciences \\ of the University of Oslo, Norway. Her work focuses on lipid-binding proteins in membrane trafficking and \\ autophagy, and their links to disease.
}

\section{Anne Simonsen}

T he major turning point in my career came when I realized that science was not simply something I loved to do, but something I could not live without. I was in the middle of a successful postdoc in Harald Stenmark's lab when I became pregnant with my first child. Parents in Norway are allowed a year of parental leave with full salary, and my husband and I decided to share the last four months of leave. Although I was very happy to go back to the work I loved and my friends in the lab, I also constantly felt bad for not spending enough time with my son. Moreover, I started doubting that I would ever become an independent investigator. I knew how much hard work and dedication it takes to become successful and I could not see how to combine this with being a good mum. People around me seemed to think differently — after all I had published two papers in Nature during the first two years of my postdoc, and was already supervising a $\mathrm{PhD}$ student. Still, I thought that this was mainly due to luck and being at the right place at the right time, and that I would soon be revealed as a poor scientist. Over the years I have realised that many women tend to think like this, and I tell my students that they should rather think more like Astrid Lingren's famous character, Pippi Longstocking, "I have never tried that before, so I think I should definitely be able to do that".

During this time of self-doubt a friend who worked in a biotech company asked if I would consider the position of senior scientist and project leader. At first I was completely against it, but with time the idea grew on me, especially the prospect of having more time with my child. The fact that the Norwegian Cancer Society funding my postdoc permitted me to take a oneyear leave helped make up my mind, as it meant that I did not have to cut all strings to the world of academia. After an emotional goodbye party with the lab, I started my new job with a lot of optimism. My new colleagues were very nice, I had a lot of responsibility, my salary was much higher than before and the working hours much shorter. I was developing new products to

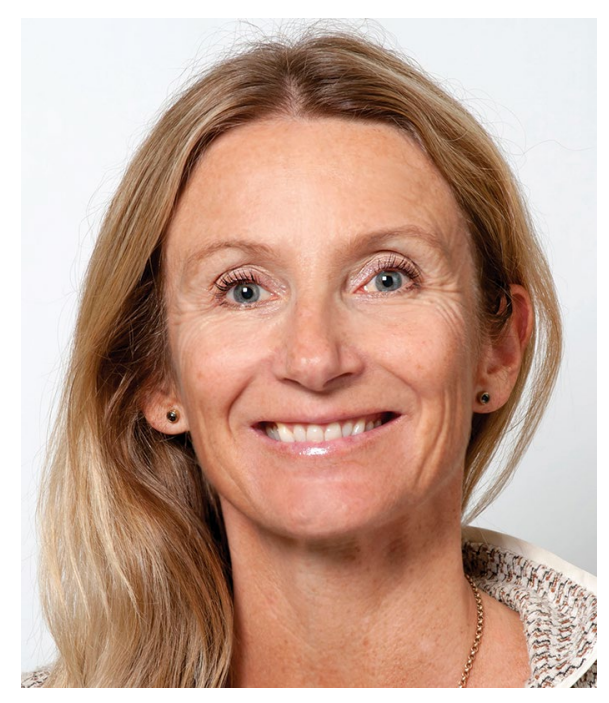

Credit: Gunnar Fredrik Lolthe, University Of Oslo

isolate immune cells from mice, oversaw lab experiments and interacted with the operations and marketing departments. I learned a lot, but I did not have to read papers or come up with new hypotheses to test, and I soon found myself missing basic science. After a while I had my second child and when I returned to work from maternity leave I started to think seriously about my career. I realized that despite my self-doubts and the challenges in combining family and work, basic research was an integral part of who I was. I knew then that I would never be truly fulfilled if I stayed in my biotech job. I decided that I would do my best as a scientist and as a mum and that I would try not to feel bad for not being perfect at either. This was an important turning point for me, because it made me feel entirely confident about pursuing an academic career and helped me find a balance when it came to family and work responsibilities.

Against this backdrop came my first steps into the field of autophagy. During my postdoc in the Stenmark lab we identified the FYVE domain as a lipid-binding region specific to phosphatidylinositol 3-phosphate (PI3P). At the time, all known FYVE-domain proteins localized to early endosomes. The human genome sequence was not yet complete and new proteins were identified all the time. I wanted to clone an uncharacterized FYVE protein and started out with a sequence containing a C-terminal FYVE domain. After months of 5'RACE reactions, followed by bacterial transformations and waiting for sequencing results, I succeeded in cloning a protein of 3526 amino acids. We raised an antibody against it, but to our great surprise, we could not detect colocalization with endosomal markers. Around this time, the Codogno lab reported that the class III PI3 kinase, and by extension its product PI3P, was required for autophagy. We decided to test whether our mystery protein was involved in this process and obtained a construct expressing the autophagy marker LC3 from the Yoshimori lab. This time our colocalization experiments were positive and my protein got a name - autophagylinked FYVE (ALFY) protein. Autophagy was still a relatively small field then and, through ALFY, I had the opportunity to establish independent collaborations and an independent line of research that eventually led to an offer from the University of Oslo to establish my own lab as a professor.

Fifteen years later, I have never regretted my decision to return to academia and to follow ALFY into the exciting world of autophagy. I have worked hard and travelled a lot, and although I have missed a few school plays, I have never missed any of my children's birthdays. My proudest moment was when my daughter in fifth grade had an assignment to write about 'My hero' and hers had the title 'My mum'.

\section{Anne Simonsen}

Department of Molecular Medicine, Institute of Basic Medical Sciences and Centre for Cancer Cell Reprogramming, Institute of Clinical Medicine, Faculty of Medicine, University of Oslo, Oslo, Norway. e-mail:anne.simonsen@medisin.uio.no

Published online: 28 August 2018 https://doi.org/10.1038/s41556-018-0156-6

Competing interests

The author declares no competing interests. 